\title{
Turkish Nationalism and Turkish Union Project
}

\author{
Elnur Hasan Mikail ${ }^{1}$, Ali Nazmi Çora ${ }^{2}$, Hakan Çora ${ }^{3}$ \\ ${ }^{1}$ Department of International Relations, Department Head, Faculty of Economics and Administrative Sciences, Kars Kafkas Uni- \\ versity, Kars, Turkey \\ ${ }^{2}$ Department of Business, Faculty of Business and Administrative Sciences, Istanbul Okan University, Istanbul, Turkey \\ ${ }^{3}$ Department of Business, Faculty of Business, San Ignacio University, Miami, FL, USA \\ Email: emikail@turansam.org, alinazmicora@gmail.com,corahakan@gmail.com
}

How to cite this paper: Mikail, E. H., Çora A. N., \& Çora, H. (2019). Turkish Nationalism and Turkish Union Project. Open Journal of Political Science, 9, 610-623. https://doi.org/10.4236/ojps.2019.94037

Received: July 26, 2019

Accepted: September 27, 2019

Published: September 30, 2019

Copyright $\odot 2019$ by author(s) and Scientific Research Publishing Inc. This work is licensed under the Creative Commons Attribution International License (CC BY 4.0).

http://creativecommons.org/licenses/by/4.0/

Open Access

\begin{abstract}
In this study, the concept of Nationalism, which is of great importance for the present day, but the subject of little research in the academic field until the beginning of the 20th century, has been researched as the emergence of nationalism movement and the ethnic basis of the nations. There is both a danger and hope in the division of people into nations, persevering the power of national identity in every corner of the world. The study is based on a project for the Turkish world. The coverage area of the project is the Turkish states; Republic of Turkey being in the first place and including Azerbaijan, Uzbekistan, Turkmenistan, Kyrgyzstan, Kazakhstan. These states with a total population of over 300 million can come together like the European Union. We can call this union the Turkish Union.
\end{abstract}

\section{Keywords}

Turkish Union Project, Ideology of Nationalism, Turkism, Turanism, Ali Bey Huseyinzade, Ataturk, Turkish World

\section{Introduction}

In this study, a new approach, which has been developed by a number of social scientists in the last one to two years, will be advocated. Moreover, the topics such as the birth of nations, ethnicity, national identity (Smith, 1999: p. 37), nation-state relations and the emergence of nationalism will be discussed. It is very interesting that the notion of Nationalism, which is such an important issue that we can show as a fundamental factor in the formation process of states, has not been the subject of an academic study until this century (Lewis, 1996: p. 45). What is surprising, however, is that nationalism, which has left its mark on social life and world politics for almost two hundred years, is only recently being 
the subject of research in the "academic" area. The origins of the idea of nationalism can be traced back to the end of the 18th century, to Herder and Fichte, or even to Kant and Rousseau according to some writers (Baydur, 2001: p. 23).

Consideration of nationalism as a social science subject goes back to the $1920 \mathrm{~s}$ and 1930s. In this period, the work of Carleton Hayes and Hans Kohn in the 1940 s puts Nationalism on the agenda of the academic world. What distinguishes them from the early works, which were produced under the influence of the ideology of nationalism and contributed or targeted to contribute to the development of nationalism, was to try to explain the subject they discussed in depth and to explain them from a comparative perspective. In later years, the increasing number of studies on Nationalism, with the effect of the disintegration of colonial empires, began to perceive Nationalism as a part or product of the modernization process, even though emphasizing on different factors (Behar, 1998: pp. 23-26). There is also the role of the modernization school, the influence of which was felt in many fields of social sciences since the 1960s. The 1980 s is accepted as a milestone by many experts of nationalism. In this period, works of theoretical content by John Armstrong, Benedict Anderson, Ernest Jellner, I.J. Hopsbawn and Anthony D. Smith were published.

The Turkic World is in a very key position today. Instead of accessing the European Union as a second-grade state, Turkey should act as a big brother to the Turkish states. With the cooperation of Azerbaijan at the first place and the Turkic states such as Uzbekistan, Turkmenistan, Kyrgyzstan, Gagauziya and other Turkic states, we will be successful in this union project by means of a coherent and rational approach (Resulzade, 1990: p. 87).

It is true; there had been people who wanted to achieve this purpose. Türkeş and Özals wanted to make it real, but they did not let it happen. But, of course, they didn't. We will do it ourselves. We will do this only by believing and trusting ourselves. Our main motto is to be sure of ourselves, to believe in ourselves and to run towards the goal with rational and coherent politics. In this context, every Turkish individual has great duties (Netcheolodon, 1996: p. 34). We must be nationalists in order to be successful. In order to be successful, we will be racist like the Jews if necessary and we will love only our own Turkish race (Billing, 2002: p. 12).

Mithat Baydur, a researcher on the concept of nationalism, says the following while giving the philosophy of Nationalism. Nationalism is divided into 4 parts:

1) Rationalism: wisdom to which importance was not attributed in the Middle Ages, has come to the forefront, and scholasticism has ended relatively.

2) Naturalism: Eyes are turned to nature. Nature has become the focal point of thought.

3) Laicism: The world itself has been the point of reference for thinking and the formation of ideas.

4) Individualism: Human is discovered. The concept of concrete and objective human being, "individual" is raised instead of an abstract and intangible human concept (Baydur, 2001: p. 37). 
In philosophical terms, we are witnessing the importance of nationalism so far as its application to the Turkish world is concerned. We do not see any concrete or abstract obstacles for the unity of these Turkish States. Then why are we crawling at the door of the European Union? For what purpose we should ignore the brotherhood of the Turkic Republics while all what EU offers us is a second-class citizenship? Our Turkish brothers have opened their arms and are waiting for his brother Turkey to give care to them. The current AKP government of Turkey is degrading such a big state like Turkey by insisting to stay at the door of the EU to secure a second-class EU membership (Baydur, 2001: p. 23).

The intellectual life of the Turks: The intellectual life of the ancient Turks begins in the religious sphere, as in other nations. Since the BC XXIV century, Turks lived in the highlands in an area called Central Asia surrounded by $\mathrm{Pa}$ mir-Hindikus Mountains in the south, the Siberian forests in the north, the Caspian sea in the west and the broad plateau bounded by China in the east. The word Shamanlik (Shamanism) passed to the Tunguz language from the Sanskritic word sramana, which means beggar cleric (Gumilev, 1991: p. 72).

On earth, resides the good souls called yersu. It is believed that the first form of Shamanism consisted of a totemism mixed with witchcraft, and that the Turks developed it. However, Turks have tried many other religions such as Buddhism, Mazdeism, Manishism, Nastatiism, Judaism and Christianity. The original intellectual life of the Turks began in Islamic culture. Farabi and Ibn Sina, the great founders of Islamic philosophy, and Şehabeddin Sühreverdi who developed this philosophy on the path of knowledge are Turkish (Rasid, 1996: p. 46).

Within the discipline of Islamic mysticism, great Turkish thinkers such as Mevlana Celaleddin, Haci Bayram, Haci Bektash and especially Shaykh Bedreddin, Simavnali, were raised. Apart from these, Turkish philosophers who worked in the fields of philosophy of religion, philosophy of mysticism, philosophy of law and politics, theology and sociology can be listed as follows: Kınalızade Ali, Molla HasanülKafi, Lütfi Pasha, Koca Şekbanbaşı, Mehmet Nahifi Efendi, Mustafa Paşa, Eşrefi Rumi, Aşık Pasa, Hacı Hüseyin's son Musa, Eşref's son Abdullah, Birgivi Mehmet, Koca Nişancı Mustafa Pasha, Durmuş' son Abdullatif, son of Idris of Bitlis Head of Provincial Treasury Mehmet, Abdülaziz of Hasan Canlar, Sururi Çelebi, Taşköprülüzade Ahmet, Nihali, Pertevi, Nerkisi, İbni Melekzade Mehmet, Muhyi, Ibni Firuz Mehmet, Lamil Celebi, Cemaluddin Mehmet Aksarayi, Shamsuddin Sivasi, Azmi, Osmanzade Ahmet Taip, Tosyalı Kucuk Mustafa, Nureddinzade Muslihuddin, Nasuh Nevali, Ibrahim Hakki of Erzurum, Ismail Hakki of Bursa, Ziya Gokalp (Rasid, 1996: p. 46).

The souls are the forces existing in matter. We are driven to both goodness and evil by our own power and we call our power of goodness angel and power of evil the devil. These forces exist not only in humans but in all bodies. Everything occurs for a reason. For example, a rainfall occurs with a cause and in result of exercise of a power. Looking for the signs of doomsday is a wait in vain. Once the body granules have disintegrated it is impossible to reunite the as it is 
also impossible to arise from dead or revitalize the dead bodies. Every good thing is heaven, every evil thing is hell, there is no hell or heaven other than what is happening in the world. The heaven and hell mentioned in the holy books "have realized in the realm of imagination". All prayers and worship are for the purification of the human being (Billing, 2002: pp. 13-14).

There is no limit, condition or form of true worship. Moreover, the divisions arose from the confusion created by the clergy, and if they were eliminated, all religions would be one. All people are the same god's sons and are brothers. Those who love and respect each other can always unite regardless of the difference of religion. The government must be formed through election. The nation must be able to use the right to vote in full freedom. Bullying should not be submitted. Ziya Gökalp (1876-1924), a sociologist, has combined the various currents of thought that have been debated since the reform effort called Tanzimat, with the formula of the "I am of the Turkish nation, the Islamic Ummah, the Western civilization" and has given a new direction to the nationalism that has been lost, especially in the Ottoman ummah (Baydur, 2001: p. 48).

He advocated new ideas such as the orientation of culture towards the people, the separation of state affairs from religion (secularism), the abandonment of the Eastern sciences leaving its place to the Western sciences, the equality of women and men in law, the examination of Turkish history by a sociological and objective method, and the consideration of the beginning of Turkish history from the first empires in Central Asia. If the thinkers of various Western nations appeared in the discipline of Christian philosophy, Turkish thinkers appeared in the discipline of Islamic philosophy (Rasid, 1996: p. 76). The first Turkish thinker outside this discipline is Ziya Gökalp. Valuable glossarists of philosophy, historians and researchers such as Ismail Fenni, Riza Tevfik, Mustafa Namık Çankı, Cemil Sena, Osman Pazarlı, Macit Gökberk and so on followed Gökalp. It is clearly seen when thoroughly examined that, for instance, the philosophical glossary of a Reza Tevfik, history of philosophy of Macit Gokberk's are far more superior in some aspects to many other examples in the West.

When we speak of the nationalist economic policy, the ideology of nationalism will naturally come to everyone's mind. When this ideology is examined deeper, it evokes racism. Naturally, since the Nationalist Economic Policy will enter the economic dictionary as a concept for the first time, it is necessary to solve the problems firstly which may be encountered due to such similitude. In order to explain this, first of all, we need to know what is National Economy. Today, when the world is a global village, we can say that if we are witnessing that the meaning of the National Economy has lost its validity, the same way that the racist ideology does not apply today in the context of a recent example of Hitler's attempt to implement it. There are some proven facts on this assumption. In other words, when talking about the global economy, a Japanese person living in Japan can order and buy any $\mathrm{x}$ goods that he sees and likes on the internet easily in the same way as electronic commerce. This is where all the 
boundaries of the world have disappeared when we look at the economy (Rohlen, 1987: p. 23).

National economy is not a concept that should be totally compared with the global economy. Because national economy policy and globalism are separate concepts and it does not seem possible to compare them. In addition, the Nationalist Economy Policy ${ }^{1}$ is not a policy example confined to a narrow space. On the contrary, its importance has increased in the global world. In this context, we will examine the economy policies of the states which exemplifies the Nationalist Economic Policy, such as Germany, Japan and Israel, which has been the master country of a totally Nationalist Economic Policy (NEP) (Rohlen, 1987: p. 34).

NEP, in general terms, can be defined as loyalty of a country to its culture and traditions and as a total of ideas supporting the development of the national economy through local initiatives in accordance with the needs of its society. To explain it at country level, for example in case of Russia; iron and steel, oil and gas products are the main and domestic natural resources of the country which Russia extracts from its territory. Russia, based on its own resources, still leads the world arms manufacturing market today. In this example, NEP is the main policy pursued. Because the production of weapons from the beginning to the last stage takes place in Russian territory begins and ends. That is why today, Kalashnikov brand name has a place in the world. Today, the Kalashnikov brand has an important place in the world arms market and is preferred to other types of weapons based on its characteristics and quality. In this context, Russia has created its own brand worldwide using its natural resources, labor force, national labor and Russian technology. In this example, NEP is mentioned (Netcheolodon, 1996: p. 47).

After the ranking of these examples, we have reached the final stage of our results. As we have seen, NEP can naturally be identified with nationalism (Baydur, 2001: p. 53). Because today when the Kalashnikov is mentioned, Russia and Russian products come to mind. Therefore, the Russian weapon in the world arms market speaks for the country. To give an example relevant to Turkey, hookah comes to mind at the moment. Hookah is known in the world market as a traditional drink specific to Turkey. I do believe that If Turkey pursues NEP policies hookah can be a product that evokes Turkey in the world market. Just because this came to my mind at the moment I am giving the example of hookah. Of course, it is an indisputable fact that the MEP project will be more efficient if applied to more useful areas. For example, just as Cuba comes to mind when Cuban cigar is mentioned or Japan comes to mind when sushi ${ }^{2}$ is mentioned, Turkey should come to mind when hookah is mentioned. Hookah is a beverage with tobacco and perhaps it is not an option to be preferred. But a kebab meal is the common meal of the whole Turkish world. Today, when kebabs are mentioned, it is not Japan or America which comes to mind. Following ${ }^{1} \mathrm{NEP}$, after that, a general abbreviation of NEP will be used instead of the nationalist economic policy.

${ }^{2}$ It is a Japanese dish made of fish, rice and seafood. 
a conscious NEP project, we may be able to make our national kebab widely known and preferred all over the world as a Turkish brand, thus getting the maximum yield. As a matter of fact, presently national Turkish food, Döner is an example of this. However, this market has to be completely Turkified and marketed to the world in the form of a hundred percent Turkish good. Just as Japan comes to mind when sushi is mentioned or Kalashnikov comes to mind when Russia is mentioned, Turkey should come to mind when Döner is mentioned. turns undisputed mention of Turkey. As there is no example of African-made Kalashnikov, there should not be German-made Döner on the market (Rohlen, 1987: p. 42).

\section{Ideas about Nationalism}

In this last chapter, the opinions of various scientists and intellectuals about $\mathrm{Na}$ tionalism, National Economy Doctrine and MEP are given. Criticism or praise, all kinds of views are given (Ozkirımli, 1999: p. 43). Opinions are the personal ideas of the people who make a complete comment and thus directly bind the people who make the comments. We've decided to include these views so that the reader can make comparisons about the issues (Baydur, 2001: p.17).

The Middle East region is important for Turkey's interests and Turkey is in favor of the preservation of the status quo in the region. In this context, they support relations with Israel. They have maintained the support of the Zionist lobby in America which is considered to have played an important role to balance the activities of the Armenian diaspora against Turkey, is among reasons for Turkish nationalists to maintain warm relations with Israel. A rather hawkish stance is taken on the subject of Iraq and the establishment of a Kurdish state in northern Iraq is considered a cause of war. MHP also supports establishing strategic alliances in the region surrounding Turkey. These include the Caucasus, the Middle East countries, friendship and cooperation agreement with the Balkans and the Eastern Mediterranean alliance to be established between Turkey and Jordan, Israel, Egypt, and Palestine. In addition to these alliances, the MHP sought to develop relations with the Turkish republics through a ministry responsible for developing relations with the newly established Turkish world (Stefanos, 1994: p. 89).

The threat and confidence perceptions of the foreign policy identity of Turkish nationalism should not contradict regional and global realities. First of all, the gap between current foreign policy of Turkey and the nationalist perceptions must be closed. The European Union process continues to be part of the diplomacy of this country, and nationalists cannot be mistaken to perceive this as a total betrayal. In addition, the party base's support for the EU is increasing as the polls conducted on the MHP base reveal. The nationalist elite should not ignore the fact that Turkish nationalism is the nationalism of Turkish people and can be reshaped with social demands for not to pay the price of lacking the empathy towards the society (Smith, 1999: p. 57). 
World wars in the early 20th century also supported and strengthened this military structure. With the First World War, the concept of ideological nation-state influenced all countries. In this period, the phenomenon of creating a national identity has gained importance in order to increase the power of the state and to keep the society living within the borders of the country together (Smith, 1999: p. 37). Therefore, nationalism has gained importance and inter-country economic, cultural and social interactions have decreased. With the strengthening of nation-states and nationalism, states have begun to establish strict control over, education policies, language and religion policies, communication, etc. In other words, nation-states have prevented the globalization of culture (Billing, 2002: p. 17).

Since 1913, the world-wide trade relations have been weakened. Because of the war and thus trade restrictions, quotas and increased customs controls, the trade was adversely affected and the boundaries between the countries were a distinctive wall. However, the threat of war has strengthened the state against the society. During this period, which lasted until the end of World War II, concepts such as democracy, human rights, and the development of civil society remained under the hegemonic pressure of ideological nation-states (Held, 1999: pp.12-20). This hegemony has also prevented the emergence and movement of societies' dynamic structures (Lewis, 1996: p. 48). Another global event that strengthened the role of the state in the economic and social spheres of the 1930s after World War I was the economic crisis of the 1930s. The years of economic upheaval and crises hampered the liberalization policies of the countries and re-enacted state intervention in the economy and other social policies. In this process, States have had a dominant position in many areas. While countries are looking for ways of getting out of this crisis, they have accepted the necessity of taking political measures as well as economic measures in overcoming the crisis. The emergence of the Soviet Union without being affected by the crisis and increasing its share in the world trade caused socialism and communism to rise in the countries affected by the crisis.

In this process, countries have followed inward policies, and an international regulatory system has not been established to overcome the crisis. The political and social environment created by the crisis years of the 1930s, paved the way for World War II, in such an environment. World War II caused the political and economic crisis to continue (Bostanci, 1999: p. 24).

ANAP (Motherland Party), stating that it policies are based on a nationalist, conservative, social justice and freemarket (Liberal Economy style) economy philosophy; emphasizes that starting with the adoption of the changing effects of globalization on societies, the task of politics is to create mechanisms that will lead to minimizing the harm of globalization in all areas, to develop local values and to integrate with the global. The center of ANAP's political approach includes the free individual, the justice society and the competitive economy. Among the main elements of the ANAP policies, as well as the liberal principles 
such as respect for individual rights and freedoms, the development of civil society dynamics, human-centered development, the establishment of a modern democracy concept, transparent and effective state, limitation of the state and bureaucracy; the social problems caused by inequality in income distribution, unemployment and poverty are emphasized and social policies relating to combating unemployment and poverty, promoting equitable income, extensification of the state support in basic education, equality of opportunity in education, a social security system that embraces all segments of society, ensuring equality between women and men in all areas, sensitiveness to the social needs of women, youth, people with disabilities and elderly people and environmental policies are given the same importance (Held, 1999: p. 24). ANAP considers this conception as an ideal meeting of economic liberalism and social justice, the area of freedom of the individual and the public interest. An understanding that targets EU membership in the center of its foreign policy, as well as an active foreign policy in the direction of becoming the leading country in the Middle East, the Balkans, the Caucasus and a guided in Eurasia (Stefanos, 1994: p. 95).

When we say "out of measure" I mean the measure of those who think with common sense. It is not because I don't know that this is the "measure" of nationalism. To be a prisoner of nationalist nonsense, it is not necessary to be ignorant. Even the people who have studied the world or become professors can get this current. Here is the latest example: words of the rector of Istanbul University, who is also physician: "we gave 25 thousand martyrs in the Southeast, we give a 45 thousand, 100 thousand more martyrs, we get Cyprus, we take, Greece also!" Look at the comfort of the man: It's like he's talking about numbers, not people! I don't know if there is any such irrational and "unscientific" discourse as a scientist (Erdogan, 2004).

You most probably know that Turkey is the only country in the world that identifies itself as "nationalist" in the civil constitution. Also, nationalism is a frequently repeated theme at the preamble of the Constitution ... Have you ever thought about what it is like, not for an individual or a political party, but for a state to be "nationalist"? We have a hard time imagining anything that can terrify people more than that. Nationalism is such a malady that infects every ideology. In particular, see the case of socialism and Islamism in Turkey. By saying these I do not mean to exculpate nationalism-free socialism or I do not mean that socialism is completely incompatible with nationalism. But it is also a fact that not only in Turkey, but in other places also, the most caricatured forms of socialism are blended with nationalism. On the other hand, look at the Islamist discourse: it is a very sad manifestation for the universalist message of Islam that a nationalist message lies at the heart of majority of Islamists' ideas as much as the pure nationalists (Rasid, 1996: p. 67)!

Nationalists are also in the habit of giving examples of the nationalism of other societies as proof of their alleged righteousness. Thus, they mean that nationalism is normalism and not being nationalist is abnormal. However, what they 
bring as evidence is one of the most important proofs showing that nationalism is wrong. As a matter of fact, world peace requires all societies to stop seeing their interests in the harm of another. Finally, it would be good to abandon the deception of separating "nationalism of Ataturk" from other nationalisms. If you look at the official discourse and academic articles (including the books of constitutional law), "nationalism of Ataturk" is not a nationalism in the usual sense. They say that "Ataturk nationalism" is not a racist, chauvinist and non-irredentist nationalism, it is a more "civilized" nationalism. In fact, however, Ataturk nationalism is also a nationalism, it is Turkish nationalism. In spite of some nuances, it is not possible to separate its theory or practice from nationalism in a familiar sense (Ozkirımli, 1999: p. 43).

The CTP defends the fight against the universal values of socialism in a local and universal context to reach a world without war and without exploitation. The CTP, which foresees EU membership with a solution in Cyprus, is determined to continue our struggle to ensure that our society and the whole of $\mathrm{Cy}$ prus have a social order based on democracy, human rights and social justice (Held, 1999: p. 73).

With the collapse of the Bretton Woods system at the beginning of the 1970s, a new era was introduced, imposing radical changes in national and international economic relations. The most basic features of this era have emerged as disappearance of economic instabilities/fluctuations, liberalization movements, disappearance of the separation of markets in national and international levels giving way to a more competitive structure and more rational distribution of resources, as well as the enormous developments in the fields of technology and communication, increase in the trading volumes of financial markets and the diversification of the financial products used. In this period, at the macro level, the existence of the structures that will prevent the crises that may be experienced in the international level as well as the full and timely announcement of data of all kinds relating to the countries in the financial system, that may affect the decisions of the market participants of the financial system have been important.

The second area of interest at the international level is social and human development. The most important actors to promote social and human development are the United Nations and its affiliated organizations. With this concept, it is argued that human resources development and social development are the best way to turn these changes into opportunities if countries face the rapid changes that deeply affect their political, social, economic and cultural structures. Economic, social and political inequalities resulting from the changes facing the world have a slowdown on economic growth and human development. High socio-economic divergence, with high rates of poverty, imbalance in income distribution and different marginal segments (women, youth, children, different religious and ethnic identities), weakens the ability of countries to capture new developments (Gumilev, 1990: p. 34). According to this policy, it is only possible to benefit from the effects of globalization and liberalization through 
human development. Here, the role of the state is to realize the democratization project by ensuring that all citizens have equal opportunities for the country. The two most important aspects of the democratization project are civil society participation and the strengthening of the private sector. These two developments will strengthen social ties and support human development. In addition, the state's interventions in some basic social services such as education and health will be its main role (Bostanci, 1999: p. 27).

Social and human development policy emphasizes that it is not enough to measure development and progress only with indicators such as total production and average income per capita. Instead, the role of such indicators in the fulfillment of human functions of people should be considered. The role of the state in this framework is to provide the material and social opportunities that will enable people to reach maturity, which will enable them to make good choices. Human beings can only be free after these facilities are provided (Nussbaum 1990).

\section{Conclusion and Recommendations}

In this study, the concept of Nationalism, which is of great importance for the present day, but which had been the subject of little research about the academic field until the beginning of the 20th century, has been researched with emphasize on the emergence of the nationalist movement and the ethnic basis of the nations (Gumilev, 1990: p.34). As we know, in recent years there has been enrichment in the nationalism literature with the swelling of the wave of nationalism all over the world. I prepared this study to differentiate and show the changes, formations and results of different national identity and national government types at the political level (Baydur, 2001: p. 67).

Distinctions existing between national identity and ethnic identity, which is based on citizenship and country/land basis, and ways of transitions are explained. National identity (Smith, 1999: p. 37), based on a rich historical material and a wide variety of examples were discussed (Gumilev, 1990: p. 34). There is both a danger and hope in the division of people into nations, persevering the power of national identity in every corner of the world. These dangers are clear enough; the spread of ethnic conflicts everywhere, and the persecution of minorities that cannot be "digested" during the course of a greater national homogeneity, justification of terror, ethnic injustice and slaughter escalated in a way difficult to understand even in the ancient times (Gumilev, 1990: p. 34). Nationalism also gives the only imagination and rationality of political solidarity, which is popular today and which provides popular enthusiasm. These are the promises of nationalism. These are the real reasons why so many people continue to identify with the nation (Smith, 1999: pp. 269-270).

As we enter the 21 st century, there is a new opportunity for the Turkic World. As the great thinker and Turkey's founder Atatürk said, this is the period resulting from the collapse of the Soviet Union as well. Now that the Soviet Union 
collapses, it is necessary to benefit from this opportunity and to implement the Turkish Union project. Unfortunately, the state of Turkey failed to do its share required for the leadership. This century is no longer a period of wars and war alliances, this is the time for alliance and union ideas are suggested. The European Union is an example for this. Turkey and other Turkic republics also have the capacity to make a TBA such as the EU-Turkey Association. It is mainly the task of Turkey. Because other states have just won their own independence, Turkey could act as a big brother for the Turkish states based on the experience of 85 years as an independent state. It is still not late and the necessary steps could be taken any time (Czegledy, 2000: p. 45).

This study is essentially the product of a series of theoretical ideas. Therefore, no concrete views have been made as to what practical results it can give. It focuses on just the idea that such a project would be very useful for Turkish World and Turkey. Turkey should well evaluate in which direction to go in the face of the new blocks and must set a good example for other Turkish states. Chasing the EU for years shadows the greatness of Turkey. Turkey should choose the path to follow adopting a revisionist approach instead of a status quo strategy in foreign politics and should adapt and renew itself to be suitable to cope with the new world (Behar, 1998: p. 14).

There are some thoughts and wishes about the future of the Turkic World. Certainly, at the beginning of these thoughts and wishes, peace, unity and solidarity come. Besides, we can say that the future developments for the Turkic World should be as follows.

Turkish World Language Association should be established and a common language dictionary should be prepared. The Turkish World, which is directly and indirectly exploited, is exploited in terms of culture also. Today, the most important issue of Turkish people is cultural degeneration. Under the influence of British, American, Russian and Chinese cultures, the Turkic World is groaning bitterly under the influence of the cultures and has not been able to achieve its own culture. Culture degeneration should be prevented. For this purpose, Turkish countries should sign joint Cultural Treaties and ensure the exchange of culture among themselves. Turkish agriculture, animal husbandry, mines and industry are in different levels of development. As long as countries support each other, economic integrity can be realized. In order to disrupt this unity, colonial countries such as the United States, England, France, Germany, Soviet Russia and China are now working with their forces. Against the economic exploitation of the Turkic World, the peoples of the entire Turkic World must cooperate. Therefore an Organization of Economic Cooperation of Turkish Countries Ekonomik (TÜRKET) should be established as soon as possible. Today, in the development of developed countries such as the United Kingdom, England, France, Germany, Soviet Russia, China, the labor of the Turkic Worlds is great. Turkish scientists have great contributions in science and technical studies of these countries. However, Turkic World cannot benefit from these con- 
tributions. In essence, the human capital drain from the modern Turkish world has reached the extreme (Lewis, 1996: p. 12). Turkish countries can complete each other's deficiencies in terms of science and technology. For this purpose, Turkish World Science and Technical Convention should be created (Dagi, 2002: pp. 7-12).

Today, Turkish language is not recognized as one of the official languages by the United Nations Organization. Yet, the languages of countries with very little population were accepted as official languages. Turkish, which is spoken by 250 million people, should be accepted as one of the official languages of the UN. The five permanent members of the member countries of the United Nations (US, UK, France, USSR and China) have the right to Veto. From these countries, USSR has been collapsed and independent states have been formed. In China, there is the East Turkestan Autonomous Republic, and the problems of this country are vetoed in B.M. The Turkish World, which now constitutes a mass of 250 million people, must be granted the "Veto Right" by the United Nations, or the "Right to Veto" of the five countries should be removed as it falls against the principle of equality.

It was seen in the World Wars that the alliances determined the consequences of the wars. In addition, the alliances established during the war significantly increased the defense power of the countries. However, when there was no language and cultural unity, the alliances were not long-term and permanent. Differences in language and culture have played an important role in the dissolution of the Warsaw Pact. On the other hand, the ethnic, linguistic and cultural differences in NATO have weakened the sanction power of this alliance (Gumilev, 1990: p. 34). A permanent and long-lasting TURKISH WORLD DEFENSE TREATY should be established, not artificial formations such as NATO and VARSHOVA TREATY. The defeats of Turks to other states in history have always been due to fights between the brothers. Even in the twentieth century, the Turkish countries remained in the captivity of both the Soviet Russia and the People's Republic of China, while a continuous brother-sister struggle continued in Turkish states. In each country or region, the Turks have been classified under various names (Tatar, Kazak, Uzbek, Uygur, Karakalpak, Kyrgyz, Azeri, Yoruk, Turkmen, etc.) and the Turkish names were forced to be forgotten and these Turkish tribes were made hostile to each other. Thus, the benefits of the colonialists were enforced inadvertently. If the Turkish people do not want to suffer in the world, they should end the discrimination based on the tribe difference and the ideal of brotherhood should be supported because "Union makes strength" (Dagi, 2002: p. 76).

If we mention the border disputes between the Turkish Republics, the present borders in the Turkish Republics should be preserved. The problems that may arise after this should be tried to be resolved in the Turkish Countries Supreme Congress to be formed. The connection of Christian Orthodox Turks to the Turkish Orthodox Patriarchate should be realized. Representative offices of the 
Republic of Turkey should be opened in all the Turkish states and any kind of aid must be provided including visa granting.

Television and radio broadcasting on TRT (Turkish Radio and Television) of the Republic of Turkey should be transmitted to all other Turkish republics and in addition to television and radio channels in Turkey and the Television and radio broadcasting of the Turkish Republics should be transmitted to Turkey: communicating with youth organizations in Turkish provinces; supporting all nationalist parties in Turkish states; increasing academic studies on the Turkish Union at universities in Turkey and the Turkish states; organizing lobbying for the removal of Russian military presence in Turkish homelands. Increase activities of the youth organizations in order for the students coming from the Turkish states to Turkey for studying, to support the idea of Turkish Union (Dagi, 2002: pp. 7-12). Increasing liaison with the political organizations in the Turkish Dormitories in addition to the Turkish World Congresses held annually. Educational institutions representing Turkey in Turkish states should be freed from the impact of this or that community, sect or group and these institutions should be taken under the control of the Turkish state.

As a result, to construct the geography of the Turkic World, which smells peace, love, brotherhood, unity and solidarity, must be the greatest aim of the youth of the Turkish World. God Bless the Turk!

Nationalist Economic Policy is a completely new idea I have never come across in any scientific literature in Turkey. The concrete examples are seen in the establishment of Japan, Germany and Israel states, which have a strong economy today. According to the conclusions I suggest that the MEP project should be implemented in Turkey (Rohlen, 1987: p. 17).

\section{Conflicts of Interest}

The authors declare no conflicts of interest regarding the publication of this paper.

\section{References}

Baydur, M. (2001). Nationalism in the Global World. Istanbul: Irfan Publishing.

Behar, B. (1998). Theories of Nationalism, Politics and Relations in Eurasia. Turkey Diary No. 50. Ankara.

Billing, M. (2002). Banal Nationalism. Istanbul: Gelenek Publishing.

Bostanci, M. N. (1999). Nationalism as a Collective Consciousness. Istanbul: Dogan Books Publishing.

Czegledy, K. (2000). Migration of Turan Tribes. Istanbul: Sarmal Publishing.

Dagi, Z. (2002). Transformation of Russia: Identity, Nationalism and Foreign Politics. Istanbul: Boyut Books.

Erdogan, M. (2004). Nationalist Delusion. Newspaper Tercuman.

Gumilev, L. N. (1990). Ethnic Geography Conception in Historical Process. Sankt-Peterburg: Nauka Publications.

Gumilev, L. N. (1991). Analysis of the Thousand Year Process around the Caspian Sea. 
Baku: Azerbaijan State Publications.

Held, D. (1999). Democracy and the Global Order: From the Modern State to Cosmopolitan Governance. London: Polity and Stanford University Press.

Lewis, B. (1996). The Emergence of Modern Turkey (6th ed.). Ankara: Turkish History Department Publications.

Netcheolodon, G. (1996). Russian Revolution and Jews (2nd ed.). Istanbul: Sebil Books Publications.

Ozkirmmli, U. (1999). Theories of Nationalism: A Critical Review. Istanbul: Sarmal Books Publications.

Rasid, A. (1996). Resurrection of Central Asia. Islam or Nationalism? Istanbul: Cep Books Publications.

Resulzade, M. E. (1990). Foundation of Azerbaijan Republic and Present Situation. Istanbul: Meryamer Publications.

Rohlen, P. T. (1987). Spiritual Education in Japan (Translated by Yazgan, Turan.). Istanbul: Turkish World Research Foundation.

Smith, A. D. (1999). National Identity(2nd ed.). Istanbul: Iletisim Publications.

Stefanos, Y. (1994). Nationalities and Borders: Balkans, Caucasus and the Middle East Istanbul. 